\title{
Comparison of Different Lactobacilli Regarding Substrate Utilization and Their Tolerance Towards Lignocellulose Degradation Products
}

\author{
Angela Gubelt ${ }^{1,2} \cdot$ Lisa Blaschke ${ }^{1,3} \cdot$ Thomas Hahn $^{4}\left(\mathbb{D} \cdot\right.$ Steffen Rupp ${ }^{1,4} \cdot$ Thomas Hirth $^{1,4,5} \cdot$ Susanne Zibek ${ }^{1,4}(\mathbb{D}$
}

Received: 2 March 2020 / Accepted: 14 July 2020 / Published online: 29 July 2020

(c) The Author(s) 2020

\begin{abstract}
Fermentative lactic acid production is currently impeded by low $\mathrm{pH}$ tolerance of the production organisms, the successive substrate consumption of the strains and/or the requirement to apply purified substrate streams. We identified Lactobacillus brevis IGB 1.29 in compost, which is capable of producing lactic acid at low $\mathrm{pH}$ values from lignocellulose hydrolysates, simultaneously consuming glucose and xylose. In this study, we compared Lactobacillus brevis IGB 1.29 with the reference strains Lactobacillus brevis ATCC 367, Lactobacillus plantarum NCIMB 8826 and Lactococcus lactis JCM 7638 with regard to the consumption of C5- and C6-sugars. Simultaneous conversion of C5- and C6-monosaccharides was confirmed for L. brevis IGB 1.29 with consumption rates of $1.6 \mathrm{~g} /(\mathrm{L} \mathrm{h})$ for glucose and $1.0 \mathrm{~g} /(\mathrm{L} \mathrm{h})$ for xylose. Consumption rates were lower for L. brevis ATCC 367 with $0.6 \mathrm{~g} /(\mathrm{L} \mathrm{h})$ for glucose and $0.2 \mathrm{~g} /(\mathrm{L} \mathrm{h})$ for xylose. Further trials were carried out to determine the sensitivity towards common toxic degradation products in lignocellulose hydrolysates: acetate, hydroxymethylfurfural, furfural, formate, levulinic acid and phenolic compounds from hemicellulose fraction. L. lactis was the least tolerant strain towards the inhibitors, whereas L. brevis IGB 1.29 showed the highest tolerance. L. brevis IGB 1.29 exhibited only $10 \%$ growth reduction at concentrations of $26.0 \mathrm{~g} / \mathrm{L}$ acetate, $1.2 \mathrm{~g} / \mathrm{L}$ furfural, $5.0 \mathrm{~g} / \mathrm{L}$ formate, $6.6 \mathrm{~g} / \mathrm{L}$ hydroxymethylfurfural, $9.2 \mathrm{~g} / \mathrm{L}$ levulinic acid or $2.2 \mathrm{~g} / \mathrm{L}$ phenolic compounds. This study describes a new strain $L$. brevis IGB 1.29 , that enables efficient lactic acid production with a lignocellulose-derived C5- and C6-sugar fraction.
\end{abstract}

\section{Introduction}

Lactic acid is a compound with a broad and promising field of application. On the one hand, it can be used as building block for polymerization to polylactic acid (PLA). On the other hand, it can be applied as platform chemical for many further products, for example acrylic acid, propylene glycol and glycerol [1-3]. Especially the increasing demand for

Susanne Zibek

Susanne.zibek@igb.fraunhofer.de

1 Institute of Interfacial Process Engineering and Plasma Technology, University Stuttgart, Nobelstraße 12, 70569 Stuttgart, Germany

2 Present Address: Institute for Bio- and Geosciences: Plant Sciences, Forschungszentrum Jülich, Jülich, Germany

3 Present Address: Sartorius Stedim Cellca GmbH, Ulm, Germany

4 Industrial Biotechnology, Fraunhofer Institute of Interfacial and Bioprocess Engineering, Stuttgart, Germany

5 Present Address: Karlsruhe Institute of Technology (KIT), Karlsruhe, Germany ethyl lactate and PLA lead to a higher production of lactic acid [4]. Currently, lactic acid is produced by chemical as well as by fermentative processes. The most widely used chemical process comprises the reaction of hydrogen cyanide with acetaldehyde to lactonitrile. A succeeding addition of mineral acids leads to lactic acid which is purified by esterification and distillation followed by hydrolysis [5]. Since the chemical synthesis is based on fossil resources and includes highly toxic as well as corrosive agents, a robust and cheap biotechnological manufacture process via fermentation is highly demanded. The fermentative production is based on the microbial conversion of carbohydrates to lactic acid. Lactic acid production was reported with a variety of wild-type strains and GMO-strains, such as Escherichia coli, Corynebacterium glutamicum and several Bacilli [6]. However, the overwhelming majority of the research work focused on lactic acid-producing bacteria commonly belonging to the order Lactobacillales. Prominent examples are Pediococcus, Enterococcus, Leuconostoc, Streptococcus, Lactobacillus and Lactococcus [7]. In the past, most promising results were obtained for Lactobacillus species. The selection of strains for lactic acid production largely depends 
on the substrate. In general, starch- or saccharose-containing plants are used as substrate for the fermentative production. However, these substrates are traditionally used in food and feed industry. To avoid competition with food and feed industry, other sources of substrates have to be identified. Since lignocellulose is the most abundant feedstock on earth [8], it represents a promising alternative. Unfortunately, the release of fermentable carbohydrates from lignocellulose is much more difficult than the saccharification of starch or other storage carbohydrates [9]. The reason for this is the rigid structure and complex composition of lignocellulose which consists of lignin, cellulose and hemicellulose. Microfibrils of cellulose are embedded in a matrix of lignin and hemicellulose, causing the need for biomass pretreatment prior to the enzymatic hydrolysis to generate fermentable mono- and disaccharides [10]. Pretreatment procedures include different chemical, physical, physico-chemical and biological methods [11]. Drawback of almost all treatments is the formation of potentially toxic or inhibiting compounds such as acetate, hydroxymethylfurfural (HMF), furfural, formate, levulinic acid and phenolic compounds due to the harsh reaction conditions [12-14]. Depending on the pretreatment method, the concentrations of degradation products differ. A well-known pretreatment method is the organosolv process that results in the solubilization and thus separation of hemicellulose together with lignin in a liquid fraction and cellulose as remaining solid fraction [15]. Lignin can be removed from the hemicellulose fraction by precipitation, enzyme treatment and/or adsorber application [16]. However, each purification step increases the expenses and thus the price of the product. The utilisation of a crude hemicellulose fraction as substrate for lactic acid production, including potentially toxic degradation products would be more economically. Therefore, robust strains for lactic acid production from lignocellulose-hydrolysates are required. Tu et al. [17] reported on a Lactobacillus plantarum isolate, which tolerated $8 \mathrm{~g} / \mathrm{L}$ furfural and $6 \mathrm{~g} / \mathrm{L} \mathrm{HMF}$ at $\mathrm{pH}$ 5.0. van der Pol et al. [18] investigated the effect of different inhibitors on growth of Lactobacillus casei DSM 20011, Lactobacillus delbrueckii DSM20073, Lactococcus lactis DSM 20481, Bacillus coagulans DSM 2314 and Bacillus smithii DSM 4216. They showed 39\% growth for L. lactis at $2.5 \mathrm{~g} / \mathrm{L}$ $\mathrm{HMF}$ and a reduction to $4 \%$ at $5 \mathrm{~g} / \mathrm{L}$ compared to the cultivation without inhibitors; a reduction of the growth performance to $37 \%$ was detected at $2.5 \mathrm{~g} / \mathrm{L}$ furfural decreasing to $7 \%$ at $5 \mathrm{~g} / \mathrm{L}$. In contrast to that, low acetic acid concentrations fostered growth $(122 \%$ at $5 \mathrm{~g} / \mathrm{L})$.

In our work we present a recently isolated strain, Lactobacillus brevis IGB 1.29 and compared its robustness towards several lignocellulose-derived inhibitors with other lactic acid-producing strains. Lactococcus lactis IO-1 JCM 7638 and Lactobacillus plantarum NCIMB 8826 were selected as representatives of the facultative hetero-fermentative strains,
Lactobacillus brevis ATCC 367 as a commercial available strain within the same Lactobacillus species. To the best of our knowledge, such a comprehensive investigation resulting in dose-response curves for all of these strains has not been performed so far. Determination of specific inhibitory concentrations for different compounds enables the prospective pre-assessment of complex substrates for lactic acid production utilising the already stated bacteria.

On the other hand, we investigated growth performance at different $\mathrm{pH}$ values ( $\mathrm{pH} 4$ and 6) since lowering the $\mathrm{pH}$ does increase the amount of protonated lactic acid. The opportunity to produce lactic acid at lower $\mathrm{pH}$ values requires a lower amount of base for neutralization and facilitates downstream processing. However, growth at low $\mathrm{pH}$ also affects microbial growth due to potential toxic effects of protonated acids [19-25]. The low $\mathrm{pH}$, therefore, may also affect the toxic effects of lignocellulose degradation products on the microorganisms.

After the pretreatment of lignocellulose with the organsolv process, solid and liquid fraction can be saccharified resulting in a mixture of C5- and C6-sugars, mainly glucose and xylose. Besides glucose, L. brevis and L. lactis IO-1 were able to utilize xylose as substrate [26,27], whereas L. plantarum is not able to use xylose unless genetically modified [27].

A mixture of glucose and xylose often leads to diauxic cell growth because of carbon catabolite repression, which was already confirmed for L. lactis IO-1 [28]. Interestingly, $L$. brevis utilises glucose and xylose as co-metabolites in parallel $[27,29]$. The newly isolated $L$. brevis IGB 1.29 was also analyzed with regard to co-metabolism of glucose and xylose.

\section{Materials and Methods}

\section{Chemicals}

All compounds applied were of technical grade. $\mathrm{pH}$ adjustment was performed with $2 \mathrm{M} \mathrm{NaOH}$ or $2 \mathrm{M} \mathrm{HCl}$ either. As not stated otherwise, deionized water was used.

\section{Pretreatment of Lignocellulose}

Wheat straw was pretreated with $1 \mathrm{~kg}$ acetone per kg solid for $1 \mathrm{~h}$ at $80^{\circ} \mathrm{C}$. After separation of acetone, the solid fraction was suspended in $50 \%$ ethanol. The resulting approach was incubated for $2 \mathrm{~h}$ at $220^{\circ} \mathrm{C}$ and 40 bar (organosolv process). The liquid extract was separated and concentrated via vacuum distillation (20-fold), resulting as hemicellulose (HC) fraction with different concentrations of the degradation products (phenolic compounds $5.1 \mathrm{~g} / \mathrm{L}$, acetate $2.2 \mathrm{~g} / \mathrm{L}$, furfural $0.01 \mathrm{~g} / \mathrm{L}$, formate $1.9 \mathrm{~g} / \mathrm{L}, \mathrm{HMF} 0.1 \mathrm{~g} / \mathrm{L}$, levulinic acid $0.2 \mathrm{~g} / \mathrm{L}$ ). The HC-fraction was applied to generate the 
dose-response-curves related to the phenolic compound concentration. The content of the phenolic compounds was measured with an adapted Folin-Ciocalteau assay [30] applying vanillin as a standard. The work was performed at Fraunhofer ICT (Pfinztal, Germany).

\section{Microorganism}

Lactococcus lactis IO-1 JCM 7638, Lactobacillus brevis ATCC 367 and Lactobacillus plantarum NCIMB 8826 were obtained from official data collections. Lactobacillus brevis IGB 1.29 was isolated by the authors from garden compost.

\section{Isolation and Determination of $L$. brevis IGB 1.29}

To isolate lactic acid-producing acid-tolerant bacteria, the enrichment was performed in low pH-medium. $100 \mathrm{~mL}$ defined enrichment medium $(5 \mathrm{~g} / \mathrm{L}$ yeast extract, $10 \mathrm{~g} / \mathrm{L}$ trypton, $15 \mathrm{~g} / \mathrm{L}$ glucose, $9.6 \mathrm{~g} / \mathrm{L}$ citrate, $\mathrm{pH} 4$ ) was inoculated with a garden compost sample suspended and homogenized in $1 \mathrm{~mL}$ tap water. The cultivation was performed in $500 \mathrm{~mL}$ shake flasks with baffles at $30{ }^{\circ} \mathrm{C}$ and $120 \mathrm{rpm}$ (Multitron incubation shaker, Infors HT, Switzerland). If glucose in the broth was completely consumed during the screening, additional glucose was added. Optical density at a wavelength of $625 \mathrm{~nm}\left(\mathrm{OD}_{625}\right)$, glucose concentration, lactic acid concentration and $\mathrm{pH}$ value were determined and observed during microbial growth. In case of lactic acid production, which was analysed by chromatographic determination, the mixed culture was subjected to serial dilution $\left(10^{-5}, 10^{-6}\right.$, $10^{-7}$ and $10^{-8}$ ) and streaked out on agar plates (2\% agar) with the enrichment medium already used for growth in liquid suspension. The isolated single colonies were transferred to a test tube with $5 \mathrm{~mL}$ enrichment medium and incubated for $48 \mathrm{~h}$ at $120 \mathrm{rpm}$ and $30^{\circ} \mathrm{C}$. Colonies were investigated concerning the formation of lactic acid: Lactic acid formers were streaked out again, repeating three times the mentioned procedure to achieve a pure culture, which was identified as L. brevis IGB 1.29 via ribotyping by the DSMZ (Deutsche Sammlung von Mikroorganismen und Zellkulturen, Braunschweig).

\section{Cultivation of Microorganisms}

Seed cultures of the different strains were prepared by picking a colony from an agar plate and putting it into a test tube with $5 \mathrm{~mL}$ MRS medium [31]. Lactobacilli were incubated at $30{ }^{\circ} \mathrm{C}$ ( L. lactis at $37{ }^{\circ} \mathrm{C}$ ) and stirred at $110 \mathrm{rpm}$ until the exponential phase was reached. Standard cultivations were in general performed with MRS medium at initial $\mathrm{pH} 6,30^{\circ} \mathrm{C}$ and $110 \mathrm{rpm}$ (Multitron incubation shaker, Infors HT, Switzerland). Cultivations for the determination of the $\mathrm{pH}$ tolerance were performed at initial $\mathrm{pH}$ values of 4 and 6 .

\section{Determination of Glucose/Xylose-Metabolism}

Investigations concerning the consumption of monosaccharides were performed at a total carbohydrate concentration between 18 and $25 \mathrm{~g} / \mathrm{L}$. However, for L. lactis, a total carbohydrate concentration of $3 \mathrm{~g} / \mathrm{L}$ was used since growth is greatly impeded at higher carbohydrate concentrations, probably due to high sensitivity to lower $\mathrm{pH}$ values based on acetic acid product formation during cultivation. To confirm the ability for simultaneous consumption, a mixture of glucose and xylose was added in a total concentration of $20 \mathrm{~g} / \mathrm{L}$. Cultures were inoculated with the seed cultures resulting in an $\mathrm{OD}_{625}$ of 0.04 . The measurement of $\mathrm{OD}_{625}$ (cell growth) and monosaccharide concentration was performed with incubation until $\mathrm{OD}_{625}$ or monosaccharide concentrations converged to a constant value.

\section{Cultivation in Presence of Lignocellulose Degradation Products}

The tolerance of the different strains concerning potential lignocellulose degradation products HMF, furfural, formate, levulinic acid and acetate was determined. Dose-response curves were used to identify certain threshold values for the growth with increasing concentrations of the inhibitors. Thus, different concentrations of the model substances were used to describe a full inhibition curve for each individual strain; the substances were applied in MRS medium: Acetate $0-91 \mathrm{~g} / \mathrm{L}$, furfural $0-37 \mathrm{~g} / \mathrm{L}$, formate $0-56 \mathrm{~g} / \mathrm{L}$, HMF 0-52 g/L, levulinic acid 0-133 g/L. Additionally, the influence of phenolic compounds contained in the HC fraction derived from the pretreatment of wheat straw was investigated in order to assess the sensitivity of the microorganisms towards this compound class. The HC fraction contained phenolics as major inhibitory compound and was applied in a concentration range from 0 to $6 \mathrm{~g} / \mathrm{L}$. To compare the toxicity of lignocellulose degradation products at different $\mathrm{pH}$ values, all experiments with different substance concentration were performed at $\mathrm{pH} 4$ and $\mathrm{pH} 6$. To evaluate the results, inhibitory concentration (IC) values were determined: $\mathrm{IC}_{10}, \mathrm{IC}_{50}$ and $\mathrm{IC}_{90}$, which describe the concentration of a model substance that leads to $10 \%, 50 \%$ and $90 \%$ inhibition of cell growth. Microorganisms were cultivated in deep well plates ( $2 \mathrm{~mL}$ volume). Main cultures were inoculated 
with seed cultures resulting in an $\mathrm{OD}_{625}$ of 0.04 . All experiments were performed in duplicates. Concentration analysis of the investigated compounds was performed at the beginning and in the stationary phase.

\section{Analysis}

Measurement of $\mathrm{OD}_{625}$ was performed with the photometer Genesys 10 UV (Thermo Fisher Scientific, USA). $\mathrm{pH}$ was measured applying $\mathrm{pH}$ indicator strips $\mathrm{pH} 0-10$ (Merck, Germany). Glucose concentration was determined using Diabur Test 5000 (Roche Diagnostics, Switzerland) or HPLC. HPLC analysis of xylose, acetate, ethanol, lactate, HMF, furfural, levulinic acid and formate was performed with the column Aminex HPX-87 H (Bio-Rad, USA) and quantified using a refractive index detector 8120 (Bischoff, Germany). The volumetric flow rate of the mobile phase $(5 \mathrm{mmol} / \mathrm{L}$ sulfuric acid) was
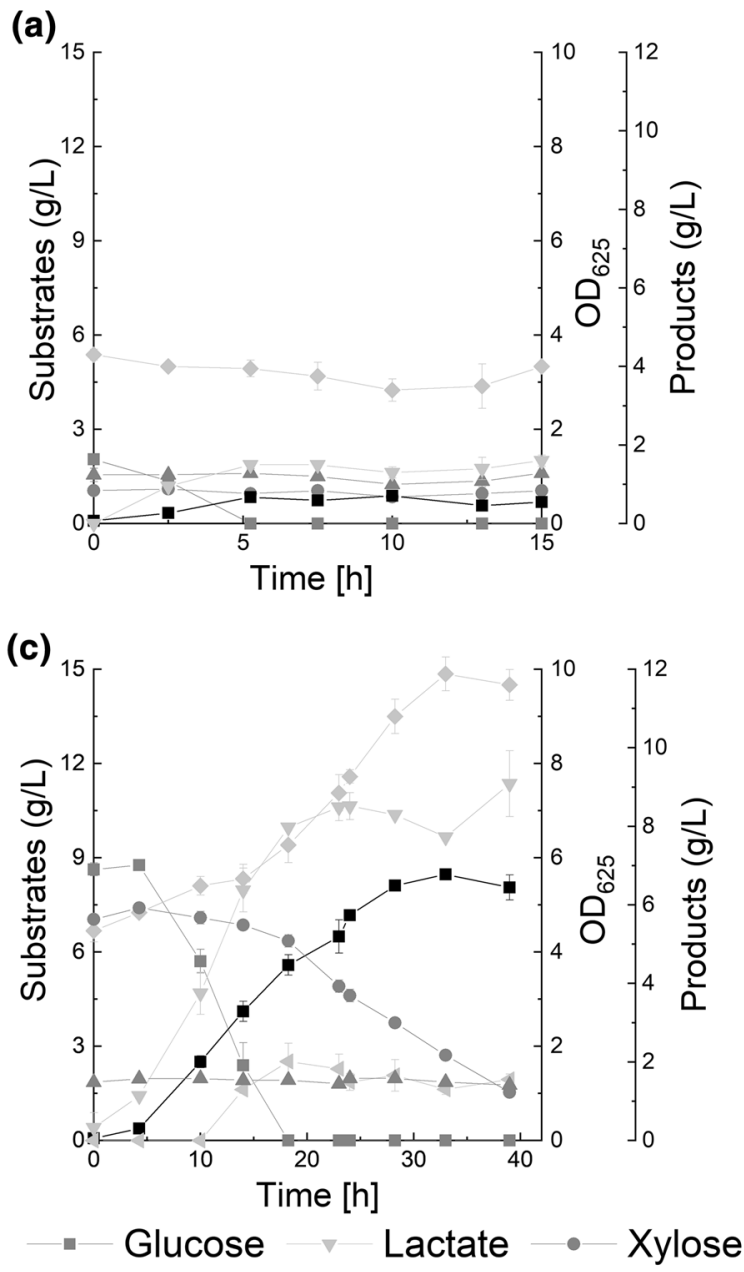

0.4 or $0.6 \mathrm{~mL} / \mathrm{min}$ at $65^{\circ} \mathrm{C}$ for different detection times up to 45 min depending on the product to be determined.

\section{Results and Discussion}

\section{Co-metabolism of Glucose and Xylose}

The general ability of the microorganisms listed in Materials and Methods to utilise glucose or xylose was preliminary investigated (data not shown). Except for L. plantarum, all microorganisms analysed were able to utilise both sugars. L. plantarum in general is not able to consume xylose, however, Okano et al. [32] reported genetic engineering works, enabling a potential xylose and thus hemicellulose utilisation by this strain. Nevertheless, we decided to subject L. plantarum to co-metabolism studies as negative control.

The co-metabolism of glucose and xylose was analysed by supplementing both monosaccharides. Growth of the
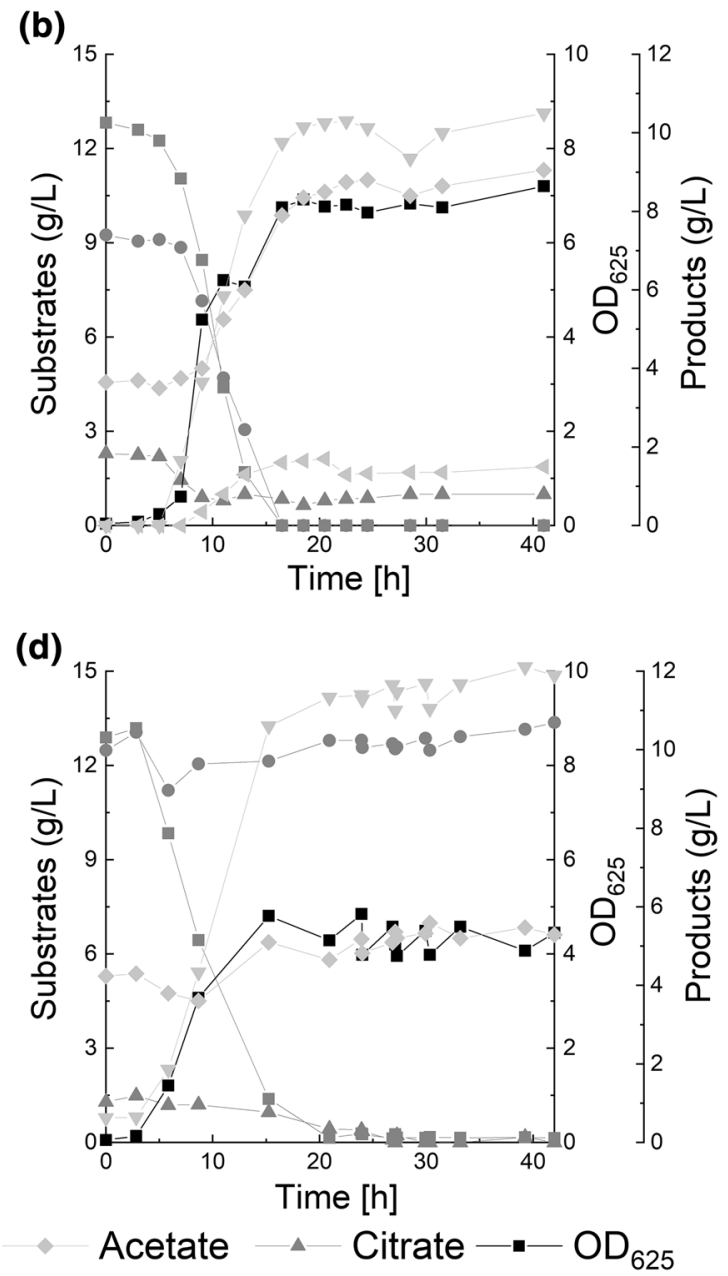

Fig. 1 Cometabolism of glucose and xylose of a L. lactis IO-1 (JCM 7638), b L. brevis IGB 1.29, c L. brevis ATCC 367, L. plantarum NCIMB 8826 and substrate (dark grey) and product (light grey) concentrations were determined by HPLC analysis 
investigated lactic acid bacteria as well as the utilisation of the sugar substrates and product formation are shown in Fig. 1.

Both $L$. brevis strains were able to consume glucose and xylose simultaneously. However, a difference between the two strains was found in the maximum sugar consumption rates (see Table 1): L. brevis IGB 1.29 demonstrated a consumption rate of $1.0 \mathrm{~g} /(\mathrm{L} \mathrm{h})$ for xylose which was about two thirds of the glucose consumption rate. L. brevis ATCC 367 consumed xylose at a maximum rate of $0.2 \mathrm{~g} /(\mathrm{L} \mathrm{h})$ representing only about one third of the glucose consumption rate. $L$. plantarum and $L$. lactis were not able to metabolize xylose in presence of glucose even after glucose depletion. The $L$. lactis strain used had already demonstrated growth on xylose and glucose as single substrate in our hands. Therefore, the co-metabolism of both monosaccharides was investigated in more detail. First, the microorganism digested the available glucose. Due to CCR, which had already been reported for L. lactis IO-1 [33, 34], this strain did not co-metabolise glucose and xylose. Its inability to consume xylose after glucose depletion was unexpected and probably due to a decrease in $\mathrm{pH}$ to $\mathrm{pH} 5.5$ and the presence of free lactic acid.

The isolated lactic acid bacterium L. brevis IGB 1.29 is a heterofermentative lactic acid bacteria. It produced $10 \mathrm{~g} / \mathrm{L}$ of the main product lactate and in addition $5 \mathrm{~g} / \mathrm{L}$ acetate and $1.4 \mathrm{~g} / \mathrm{L}$ ethanol. The same product spectrum was observed for $L$. brevis ATCC 367 with concentrations of $9.1 \mathrm{~g} / \mathrm{L}$ lactate, $6.3 \mathrm{~g} / \mathrm{L}$ acetate and $1.6 \mathrm{~g} / \mathrm{L}$ ethanol. The yield of lactate with regard to the consumed monosaccharides was $0.5 \mathrm{~g} / \mathrm{g}$ for both microorganisms, and related to $\mathrm{OD}_{625}$ the yield was $1.5 \mathrm{~g} / \mathrm{OD}_{625}$ and $1.7 \mathrm{~g} / \mathrm{OD}_{625}$, respectively. Because of the homofermentative metabolism of L. plantarum and L. lactis, they produce lactate as only product and thus yielded the highest coefficients of $0.9 \mathrm{~g} / \mathrm{g}$ and $0.5 \mathrm{~g} / \mathrm{g}$ with regard to the substrates and $3 \mathrm{~g} / \mathrm{OD}_{625}$ and $2 \mathrm{~g} / \mathrm{OD}_{625}$ with regard to the $\mathrm{OD}$, respectively.

The results confirmed the findings of other authors describing the ability of all $L$. brevis species to co-ferment glucose and xylose simultaneously [27, 29, 35-37]. On the other hand, the observed sugar consumption rates were strain-specific characteristics: L. brevis IGB 1.29 consuming glucose 2.7 times faster and xylose 5 times faster than L. brevis ATCC 367 . Consumption rates of related L. brevis strains were reported to be between those for the strains in this work, with maximum rates of $0.5 \mathrm{~g} /(\mathrm{L} \mathrm{h})$ for glucose and $0.47 \mathrm{~g} /(\mathrm{L} \mathrm{h})$ for xylose [35]. This qualifies $L$. brevis IGB 1.29 as a potential candidate for utilisation of lignocellulose hydrolysates as substrate. However, the simultaneous consumption of glucose and xylose is known for numerous L. brevis strains [35, 38]. The authors concluded that a relaxation of xylose-depending CCR might be responsible for this. L. brevis uses a specific $\mathrm{H}^{+}$-symporter which exploits the proton motive force for sugar transport [39-41]. In presence of glucose, the transport mechanism of a secondary monosaccharide switches from the $\mathrm{H}^{+}$-symporter to facilitated diffusion. As a result, the secondary sugar transport follows the concentration gradient so that, as long as the concentration is higher in the culture medium than in the cytosol, a flux of the sugar into the cytosol is maintained. The remaining repressing mechanism is apparently not strong enough to inhibit xylose metabolism. Due to this favourable trait, L. brevis is a promising candidate for lactate production from lignocellulose hydrolysates. Other microorganisms, like Bacillus subtilis, Clostridium acetobutylicum, Kluyveromyces marxianus or S. cerevisiae (genetically modified) were reported to be negatively affected by CCR during cultivation in presence of both, xylose and glucose [42-45].
Table 1 Substrate consumption and product formation by $L$. brevis IGB 1.29., L. brevis ATCC 367, L. plantarum NCIMB 8826 and L. lactis IO-1 JCM 7638 during cometabolism of glucose and xylose

\begin{tabular}{|c|c|c|c|c|}
\hline & $\begin{array}{l}\text { L. brevis IGB } 1.29 \\
(32 \mathrm{~h})\end{array}$ & $\begin{array}{l}\text { L. brevis ATCC } 367 \\
(39 \mathrm{~h})\end{array}$ & L. plantarum (39 h) & L. lactis $(15 \mathrm{~h})$ \\
\hline \multicolumn{5}{|c|}{ Glucose consumption } \\
\hline$(\mathrm{g} / \mathrm{L})$ & $12.8 \pm 0$ & $8.6 \pm 0.2$ & $12.9 \pm 0$ & $2.1 \pm 0.07$ \\
\hline$(\%)$ & 100 & 100 & 100 & 100 \\
\hline \multicolumn{5}{|c|}{ Xylose consumption } \\
\hline$(g / L)$ & $9.25 \pm 0$ & $7.9 \pm 0.14$ & 0 & 0 \\
\hline$(\%)$ & 100 & 68.4 & 0 & 0 \\
\hline $\begin{array}{l}Y_{\text {Lactate/suga }} \\
(\mathrm{g} / \mathrm{g})\end{array}$ & 0.5 & 0.5 & 0.9 & 0.5 \\
\hline$Y_{\text {Lactate }} / O D$ & & & & \\
\hline $\begin{array}{l}{\left[\mathrm{g} \mathrm{OD}_{625}\right]} \\
\text { r(glucose })\end{array}$ & 1.5 & 1.7 & 3 & 2 \\
\hline $\begin{array}{l}{[\mathrm{g} /(\mathrm{L} \mathrm{h})]} \\
r(x y l o s e)\end{array}$ & 1.6 & 0.6 & 0.7 & 0.4 \\
\hline$[\mathrm{g} /(\mathrm{L} \mathrm{h})]$ & 1.0 & 0.2 & 0 & 0 \\
\hline
\end{tabular}


L. plantarum did not metabolize xylose which had already been shown by several authors [46-49]. Attempts to genetically modify this species resulted in a strain which was able to co-metabolise glucose and xylose [32]. However, it was described that the specific consumption rate for xylose was less than $50 \%$ of that of glucose.

\section{Influence of Lignocellulose Degradation Products}

The evaluation of the microorganisms' tolerance towards lignocellulose degradation products with respect to cell growth was carried out at different concentrations of acetate, formate, furfural, HMF, levulinic acid or HC-fraction compounds. Non-inhibited growth is set to $100 \%$. Results are shown in the form of dose-response curves in Fig. 2.

L. brevis IGB 1.29 was highly tolerant towards acetate. The $\mathrm{IC}_{10}$ of acetate was determined as $25.5 \mathrm{~g} / \mathrm{L}$. Compared to the other strains the data generated revealed a decreasing tolerance in the order L. brevis IGB $1.29(25.5 \mathrm{~g} / \mathrm{L})$, L. brevis ATCC $367(19.2 \mathrm{~g} / \mathrm{L})$, L. lactis $(10.2 \mathrm{~g} / \mathrm{L})$ and L. plantarum $(9.0 \mathrm{~g} / \mathrm{L})$. Formate affected the growth of the microorganisms already at lower concentrations. A $10 \%$ inhibition was detected for L. brevis IGB 1.29 at a concentration of $10.3 \mathrm{~g} / \mathrm{L}$, whereas the concentration for $\mathrm{IC}_{10}$ of L. plantarum already was at $0.2 \mathrm{~g} / \mathrm{L}$. In contrast, the $\mathrm{IC}_{10}$ of $6.9 \mathrm{~g} / \mathrm{L}$ determined for $L$. plantarum in the presence of furfural was higher than the values obtained for the other bacteria. A higher tolerance could also be shown in the case of levulinic acid and HMF with $\mathrm{IC}_{10}$ values of $42 \mathrm{~g} / \mathrm{L}$ and $8.0 \mathrm{~g} / \mathrm{L}$, respectively.

As many different phenolic compounds can be present in the liquid hemicellulose fraction after pretreatment [50], growth experiments were carried out with a dilution series of this fraction to adjust different total phenol concentration. It has to be taken into account that the fraction contained other inhibitory substances as well, but each below inhibitory concentrations according to our investigations (see above). However, synergistic effects between the toxic compounds may exist and the $\mathrm{IC}_{10}$ values can therefore not exclusively be attributed to phenolics alone. The application of the complex hydrolysate fraction thus enables a more realistic
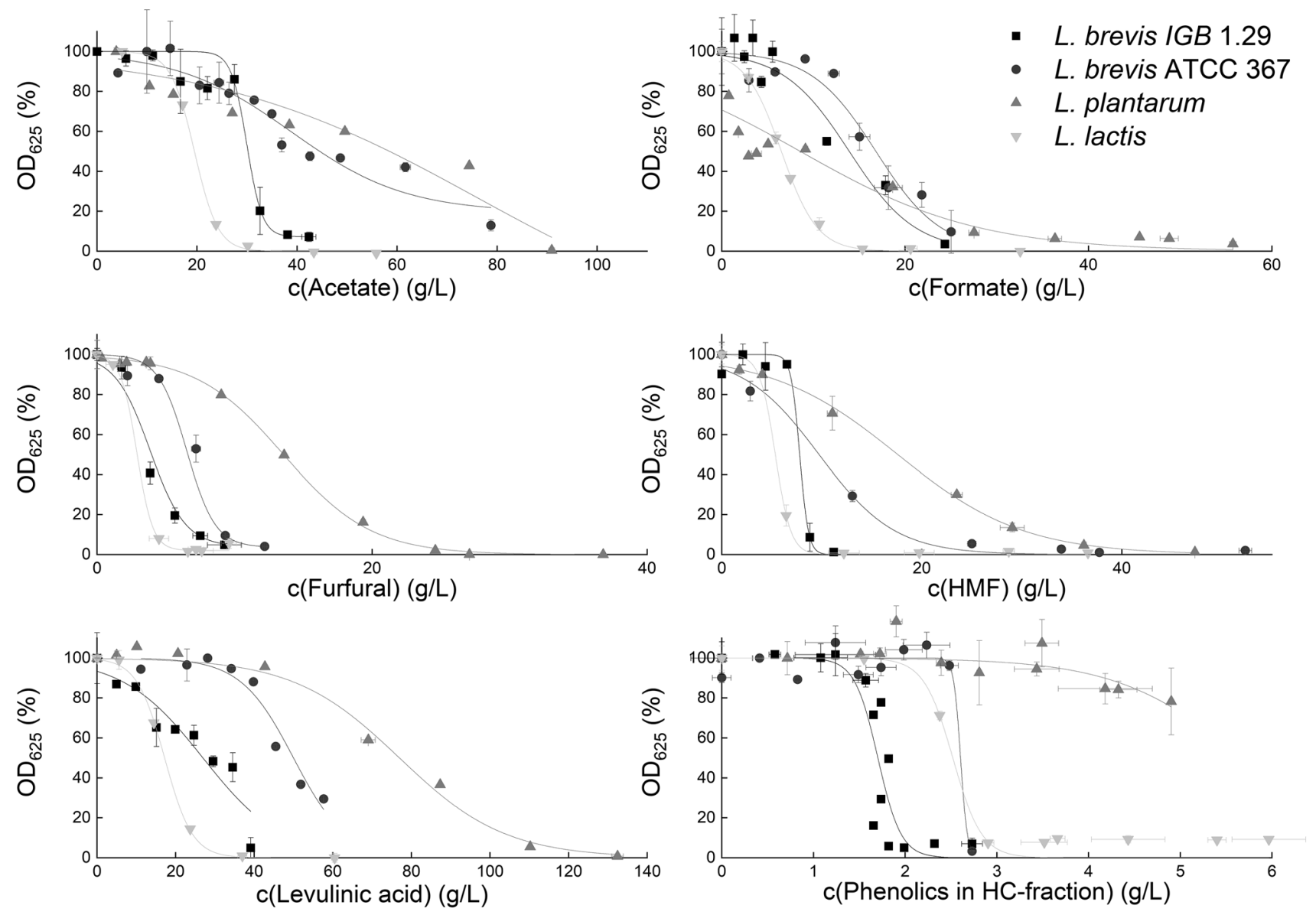

Fig. 2 Effects of lignocellulose degradation products on cell growth of L. brevis IGB 1.29, L. brevis ATCC 367, L. plantarum NCIMB 8826 and L. lactis IO-1 JCM 7638 visualized as dose-response curves 
general assessment of the lignocellulosic hydrolysate rather than using one specific phenolic compound.

The data of cultures containing hemicellulose fraction revealed that $L$. plantarum, compared to the other tested microorganisms, showed a high tolerance and exhibits an $\mathrm{IC}_{10}$ at $3.7 \mathrm{~g} / \mathrm{L}$. Since L. plantarum showed robust growth in presence of HMF, furfural and phenols, it can be stated that the strain shows a high tolerance towards aromatic compounds in general. Drawback of this strain is the low $\mathrm{IC}_{10}$ value for formate being significantly below the other microorganisms' values. Thus, formate would need to be removed to apply $L$. plantarum for the conversion of monosaccharides into lactic acid in hemicellulose fractions. L. brevis ATCC 367 showed $10 \%$ inhibition of cell growth at a phenol concentration of $1.44 \mathrm{~g} / \mathrm{L}$. In general, L. lactis showed the highest sensitivity towards the presence of lignocellulose degradation products. In order to increase the tolerance, there is the opportunity to adapt microorganisms to toxic substances in repeating subcultivations or in continuous fermentation as shown for P. stipites, S. cerevisiae, Z. mobilis strain 8b and Scheffersomyces stipitis [48, 49, 51, 52].

The inhibitory concentrations determined for the lactic acid producers presented in this study are in a comparable range to other authors' results for Pseudomonas taiwanensis VLB120, Candida tropicalis, and different Lactobacillus species [53-55]. An overview of a selected literature using L. brevis, L. lactis and L. plantarum and investigating glycose, xylose or LC-hydrolysates and shown sensitivity to LC-degradation compounds is shown in Table 2.

It should be noticed that in the presented work, the phenol experiments were done with a complex mixture. Synergistic effects of these various compounds might have led to decreased tolerance of the lactic acid bacteria presented in this work compared to the single model substance vanillin. However, the investigations performed within our study provided increased significance with regard to a prospective application of lignocellulose-derived fractions.

The reported growth data indicate that the investigated lactic acid bacteria are much more tolerant towards lignocellulose degradation products compared to several other common bacteria and yeasts as discussed above. The determined threshold values will enable a targeted concentrationoriented adjustment of the inhibitory compounds by adapting pretreatment parameters or by targeted purification of the hydrolysate.

\section{Influence of Low pH}

Microbial growth of the L. brevis IGB 1.29 has been investigated at different initial $\mathrm{pH}$ values to determine if cultivation at $\mathrm{pH}<6$ is feasible. So far, only inconsistent results for cell growth of L. brevis at various culture conditions with regulated or unregulated $\mathrm{pH}$ have been published $[4,5,11,12]$. The $\mathrm{pH}$ optimum of 5-7 (set to $100 \%$ growth) was identified by microbial cultivation at different starting $\mathrm{pH}$-values. At pH 4 and without inhibitors, the microbial growth inhibition equaled $19 \%$ compared to growth at $\mathrm{pH} 6$. Lactic acid production has not been affected at $\mathrm{pH} 4$ for the selected culture conditions. At $\mathrm{pH} 3$ no growth was detected (data not shown). These results show that lowering the $\mathrm{pH}$ from $\mathrm{pH} 6$ to $\mathrm{pH} 4$ is feasible for the lactic acid fermentation process for L. brevis IGB 1.29. According to the Henderson-Hasselbalch

Table 2 Overview of selected literature using L. brevis, L. plantarum and L. lactis investigating growth on lignocellulose hydrolysates and/or measuring sensitivity against LC-degradation products

\begin{tabular}{|c|c|c|c|c|c|c|}
\hline & Ssp. & $\mathrm{C}$-source & Sensitivity against LC-degradation products & Yield $(\mathrm{g} / \mathrm{g})$ & Product. [g/(L h)] & Literature \\
\hline \multirow[t]{3}{*}{ L. brevis } & ATCC 367 & Glucose, xylose $\mathrm{a}^{\mathrm{a}}$ & - & $0.52-0.70$ & $0.36-0.58$ & {$[27,29,56]$} \\
\hline & S3F4 & Glucose, $x y l o s e^{a}$ & $<20 \mathrm{mM}$ furfural & - & 0.68 & {$[36]$} \\
\hline & ATCC 14869 & Glucose, xylose $\mathrm{a}^{\mathrm{a}}$ & - & 1.01 & - & {$[35]$} \\
\hline \multirow[t]{3}{*}{ L. lactis } & DSM 20481 & Glucose & $\begin{array}{l}4 \% \text { growth with } 4 \mathrm{~g} / \mathrm{L} \text { HMF; } 7 \% \text { growth with } \\
5 \text { g/L furfural, } 122 \% \text { growth with } 5 \mathrm{~g} / \mathrm{L} \\
\text { acetate; } 74 \% \text { growth with } 10 \mathrm{~g} / \mathrm{L} \text { levulinic } \\
\text { acid }^{\mathrm{b}}\end{array}$ & - & - & [18] \\
\hline & IO-1 JCM 7638 & Glucose, xylose & - & - & - & [26] \\
\hline & & Xylose & - & - & 0.68 & {$[57]$} \\
\hline L. plantarum & Isolated strain & LC-hydrolysates & $\begin{array}{l}\text { Growth possible with } 8 \mathrm{~g} / \mathrm{L} \text { furfural, } 6 \mathrm{~g} / \mathrm{L} \\
\text { HMF } \\
+\end{array}$ & - & Up to 1.9 & {$[17]$} \\
\hline
\end{tabular}

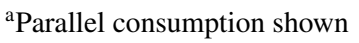

${ }^{\mathrm{b}}$ Glycolic acid, formic acid, acetosyringgone, syringaldehyde, vanillin, benzaldehyde, coumaric acid, ferulic acid were also tested

- not shown

+ there were also tested: vanillin and syringaldehyde
} 
equation lowering the $\mathrm{pH}$ from $\mathrm{pH} 6$ to $\mathrm{pH} 4$ would result in an equilibrium shift to the protonated form of lactic acid from $0.7 \%$ at $\mathrm{pH} 6$ to $41.5 \%$ at $\mathrm{pH} 4$. Hence, in the obligate step of acidification during recovery of the protonated product after fermentation, the amount of added acid could be reduced by $40 \%$, as well as the by-product formation.

Lactic acid fermentation from lignocellulose hydrolysates at low $\mathrm{pH}$ does not only influence cell growth and the amount of protonated lactic acid in solution but also the chemical state of the lignocellulose degradation products. The influence of $\mathrm{pH} 4$ on the toxicity of the lignocellulose degradation products acetate, formate, levulinic acid, HMF, furfural and hemicellulose faction with phenolic compounds was tested for L. brevis IGB 1.29 and compared to the results at pH 6 (see Fig. 2). Results are shown in Table 3.

For acetate, the $\mathrm{IC}_{10}$ value at $\mathrm{pH} 6(25.5 \mathrm{~g} / \mathrm{L})$ was about four times higher than at $\mathrm{pH} 4(5.3 \mathrm{~g} / \mathrm{L})$. Even more obvious was the influence of the $\mathrm{pH}$ value for formate. At $\mathrm{pH} 6$, $4.8 \mathrm{~g} / \mathrm{L}$ formate led to $10 \%$ inhibition of cell growth. This is a 14 times higher tolerated concentration than at $\mathrm{pH} 4$ $(0.3 \mathrm{~g} / \mathrm{L})$. Concerning furfural and $\mathrm{HMF}$, the influence of the $\mathrm{pH}$ value was less significant. The $\mathrm{IC}_{10}$ of furfural has been increased at $\mathrm{pH} 4$ from $1.2 \mathrm{~g} / \mathrm{L}(\mathrm{pH} 6)$ to $1.5 \mathrm{~g} / \mathrm{L}$. However the $\mathrm{IC}_{90}$ of $4.0 \mathrm{~g} / \mathrm{L}(\mathrm{pH} 4)$ was increased to $7.3 \mathrm{~g} / \mathrm{L}$ at $\mathrm{pH} 6$. For HMF the $\mathrm{IC}_{10}$ of $6.6 \mathrm{~g} / \mathrm{L}$ at $\mathrm{pH} 6$ was lowered to $5.8 \mathrm{~g} / \mathrm{L}$ at $\mathrm{pH}$ 4. Concerning levulinic acid, there has only been a slight influence of the $\mathrm{pH}$ value on the $\mathrm{IC}_{10}$ value $(7.9 \mathrm{~g} / \mathrm{L}$ at $\mathrm{pH} 4$ and $9.2 \mathrm{~g} / \mathrm{L}$ at $\mathrm{pH} 6$ ). However, the $\mathrm{IC}_{90}$ showed a much lower concentrations at $\mathrm{pH} 4(11.1 \mathrm{~g} / \mathrm{L})$ compared to $\mathrm{pH} 6$ $(38.0 \mathrm{~g} / \mathrm{L})$. The influence of phenolic compounds was twice as high at $\mathrm{pH} 4$ than at $\mathrm{pH} 6$. The $\mathrm{IC}_{10}$ at $\mathrm{pH} 4$ was already reached at a concentration of $0.8 \mathrm{~g} / \mathrm{L}$ phenolic compounds

Table 3 Summary of the inhibitory concentrations of the lignocellulose degradation products acetate, formate, furfural, $\mathrm{HMF}$, levulinic acid and phenolic compounds leading to $10 \%\left(\mathrm{IC}_{10}\right), 50 \%\left(\mathrm{IC}_{50}\right)$ and $90 \%\left(\mathrm{IC}_{90}\right)$ inhibited cell growth of $L$. brevis IGB 1.29 at different $\mathrm{pH}$ values ( $\mathrm{pH} 4$ and $\mathrm{pH} 6)$

\begin{tabular}{lcccc}
\hline & $\mathrm{pH}$ & $\mathrm{IC}_{10}(\mathrm{~g} / \mathrm{L})$ & $\mathrm{IC}_{50}(\mathrm{~g} / \mathrm{L})$ & $\mathrm{IC}_{90}(\mathrm{~g} / \mathrm{L})$ \\
\hline Acetate & 4 & 6.4 & 9.8 & 13.4 \\
Formate & 6 & 25.5 & 30.2 & 37.5 \\
& 4 & 0.3 & 1.1 & 2.2 \\
Furfural & 6 & 4.8 & 12.4 & 21.1 \\
& 4 & 1.5 & 2.7 & 4.0 \\
HMF & 6 & 1.2 & 3.7 & 7.3 \\
& 4 & 5.8 & 8.5 & 10.6 \\
Levulinic acid & 6 & 6.6 & 7.9 & 9.2 \\
\multirow{3}{*}{ HC fraction with phenols } & 4 & 0.8 & 0.9 & 1.0 \\
& 4 & 7.9 & 9.4 & 11.1 \\
& 6 & 9.2 & 25.7 & 38.0 \\
\hline
\end{tabular}

The curves are shown for $\mathrm{pH} 6$ in Fig. 2 compared to $1.4 \mathrm{~g} / \mathrm{L}$ at $\mathrm{pH} 6$. It was similar for the $\mathrm{IC}_{90}$ value at $1 \mathrm{~g} / \mathrm{L}$ for $\mathrm{pH} 4$ and at $2 \mathrm{~g} / \mathrm{L}$ for $\mathrm{pH} 6$.

Consequently, $\mathrm{pH}$ had a strong influence on the toxicity of the organic acids acetate, levulinic acid and formate which is due to their $\mathrm{p} K_{\mathrm{a}}$-values and of the hemicellulose fraction (with phenolic compounds). The toxicity of the organic acids depends on the diffusion of the protonated acids into the cell, where they cause a decrease of $\mathrm{pH}$ affecting intracellular processes. Compared to the other organic acids acetic and levulinic acid, formate revealed the largest influence regarding cell growth. At $\mathrm{pH} 4$ the $\mathrm{IC}_{10}, \mathrm{IC}_{50}$ and $\mathrm{IC}_{90}$ - values have been $90 \%$ lower than at $\mathrm{pH} 6$. Compared to the other organic acids, formate has the lowest $\mathrm{p} K_{\mathrm{a}}$-value (3.75) but also the lowest molecular weight $(46.03 \mathrm{~g} / \mathrm{mol})$ so it can easily diffuse into the cell. Applying acetate at $\mathrm{pH} 4$ the $\mathrm{IC}_{10}, \mathrm{IC}_{50}$ and $\mathrm{IC}_{90}$ was decreased by $70 \%$ compared to $\mathrm{pH} 6$. For levulinic acid the low $\mathrm{pH}$ affected only $\mathrm{IC}_{50}$ and $\mathrm{IC}_{90}$ significantly by a reduction of $65-70 \%$ compared to $\mathrm{pH} 6$. The $\mathrm{p} K_{\mathrm{a}}$-values of acetate $\left(\mathrm{p} K_{\mathrm{a}}=4.75\right)$ and levulinic acid $\left(\mathrm{p} K_{\mathrm{a}}=4.66\right)$ are very similar. The stronger influence of acetate might again depend on the molecular weight which is $60.05 \mathrm{~g} / \mathrm{mol}$ for acetate in respect to $116.11 \mathrm{~g} / \mathrm{mol}$ for levulinic acid. Supporting these statements, Huang et al. had described the organic acids as main inhibitors for yeasts especially at low $\mathrm{pH}$, while the hemicellulose fraction (with phenolic compounds) had a minor influence [58].

The toxicity of phenolic compounds has been shown to be increased by low $\mathrm{pH}$. At $\mathrm{pH} 4$ the $\mathrm{IC}_{10}, \mathrm{IC}_{50}$ and $\mathrm{IC}_{90}$ values were $50 \%$ lower than compared to $\mathrm{pH}$. The decomposition of lignin leads to phenolic acids, alcohols, aldehydes or ketones, depending on the side groups of the lignin [59, 60]. The hydroxyl groups of phenolic aldehydes and ketones have the lowest $\mathrm{p} K_{\mathrm{a}}$-value of 7.3-8.2. The $\mathrm{p} K_{\mathrm{a}}$-value of the hydroxyl group of phenolic acids is $9-11$. The $\mathrm{p} K_{\mathrm{a}}$-value of the acid group is between 3.4 and 4.6 [60]. This means that already at $\mathrm{pH} 6$ all hydroxyl groups of the phenolic compounds are protonated. Mussatto et al. stated that an additional decrease in $\mathrm{pH}$ only influences the protonation of the acid group of phenolic acids [61], which is $50 \%$ at $\mathrm{pH} 4$ and $0.1 \%$ at $\mathrm{pH} 6$ leading to higher toxicity at $\mathrm{pH} 4$. It has to be taken into account that the fermentations were carried out with a dilution series of the hemicellulose fraction of the organosolv process to adjust different phenol concentrations. This is why the fraction contained other inhibitory substances also being affected by $\mathrm{pH}$.

Huang et al. considered the inhibiting effect of a total hydrolysate on $S$. cerevisiae at different $\mathrm{pH}$ values $(\mathrm{pH}$ 4.5-9) without differentiation between the potential inhibitors. Within these investigations, the influence of the $\mathrm{pH}$ value on the hydrolysate toxicity could be demonstrated [58]. The data presented here confirm the influence of $\mathrm{pH}$ on the toxicity for each single lignocellulose degradation product. On the basis of the single compound concentrations in 
the hydrolysates, the inhibition of L. brevis IGB 1.29 being cultivated at $\mathrm{pH} 4$ can be predicted.

The wheat straw-derived hemicellulose fraction in this work led to significant inhibition of L. brevis ATCC 367 at $\mathrm{pH} 4$ in particular because of $5.1 \mathrm{~g} / \mathrm{L}$ phenolic compounds. Taking the results of this work into account, and not considering potential synergistic effects of different lignocellulose degradation products, this concentration has to be reduced to $1.4 \mathrm{~g} / \mathrm{L}$ for a successful cultivation at $\mathrm{pH} 4$. The concentrations of all other lignocellulose degradation products are not inhibiting.

\section{Conclusion}

Lactobacillus brevis IGB 1.29 has been isolated from compost samples. The strain was characterized and compared to L. brevis ATCC 367, L. plantarum and L. lactis with regard to xylose and glucose metabolism and tolerance towards several common toxic compounds. L. brevis IGB 1.29 is able to co-metabolise glucose and xylose with comparably high xylose consumption rates. The tolerances towards each single lignocellulose degradation product, acetate, formate, levulinic acid, HMF, furfural and phenolic compounds was determined and exceeds in general the IC values reported for other tested lactic acid bacteria and published results. Inhibitory concentrations were also measured at $\mathrm{pH} 4$, which is the lowest $\mathrm{pH}$ at which cultivation of $L$. brevis IGB 1.29 is feasible. Important thresholds for the concentrations of lignocellulose degradation products have been determined to select suitable lignocellulosic raw materials and pretreatment methods with adapted concentrations of toxic compounds.

Acknowledgements Open Access funding provided by Projekt DEAL. The research work was funded by the German federal ministry of Education and Research (Grant agree number 0315192). For the provision of lignocellulose fractions we thank Mr. Gerd Unkelbach from the Fraunhofer Institute for Chemical Technology/ Fraunhofer Center for Chemical-Biotechnological Processes.

\section{Compliance with Ethical Standards}

Conflict of interest All authors contributed to the given publication, agreed to publish in Current Microbiology and declared that there is no conflict of interest.

Research Involving Human and Animal Rights The research did not involve whether human participants nor animals.

Open Access This article is licensed under a Creative Commons Attribution 4.0 International License, which permits use, sharing, adaptation, distribution and reproduction in any medium or format, as long as you give appropriate credit to the original author(s) and the source, provide a link to the Creative Commons licence, and indicate if changes were made. The images or other third party material in this article are included in the article's Creative Commons licence, unless indicated otherwise in a credit line to the material. If material is not included in the article's Creative Commons licence and your intended use is not permitted by statutory regulation or exceeds the permitted use, you will need to obtain permission directly from the copyright holder. To view a copy of this licence, visit http://creativecommons.org/licenses/by/4.0/.

\section{References}

1. Dusselier M, Van Wouwe P, Dewaele A, Makshina E, Sels BF (2013) Lactic acid as a platform chemical in the biobased economy: the role of chemocatalysis. Energ Environ Sci 6(5):14151442. https://doi.org/10.1039/C3EE00069A

2. Grasselli RK, Trifirò F (2017) Acrolein and acrylic acid from biomass. Rend Lincei 28(1):59-67. https://doi.org/10.1007/s1221 0-017-0610-6

3. Lari GM, Pastore G, Haus M, Ding YY, Papadokonstantakis S, Mondelli C, Perez-Ramirez J (2018) Environmental and economical perspectives of a glycerol biorefinery. Energ Environ Sci 11(5):1012-1029. https://doi.org/10.1039/c7ee03116e

4. Subramanian MR, Talluri S, Christopher LP (2015) Production of lactic acid using a new homofermentative Enterococcus faecalis isolate. Microb Biotechnol 8(2):221-229. https://doi. org/10.1111/1751-7915.12133

5. Ameen SM, Caruso G (2017) Chemistry of lactic acid. In: Parisi $\mathrm{S}$ (ed) Lactic acid in the food industry. Springer International Publishing, Cham, pp 7-17. https://doi.org/10.1007/978-3-31958146-0_2

6. Abdel-Rahman MA, Tashiro Y, Sonomoto K (2013) Recent advances in lactic acid production by microbial fermentation processes. Biotechnol Adv 31(6):877-902. https://doi.org/10.1016/j. biotechadv.2013.04.002

7. Juturu V, Wu JC (2016) Microbial production of lactic acid: the latest development. Crit Rev Biotechnol 36(6):967-977. https:// doi.org/10.3109/07388551.2015.1066305

8. Rosales-Calderon O, Arantes V (2019) A review on commercial-scale high-value products that can be produced alongside cellulosic ethanol. Biotechnol Biofuels 12(1):240. https://doi. org/10.1186/s13068-019-1529-1

9. Okano K, Tanaka T, Ogino C, Fukuda H, Kondo A (2010) Biotechnological production of enantiomeric pure lactic acid from renewable resources: recent achievements, perspectives, and limits. Appl Microbiol Biotechnol 85(3):413-423. https://doi. org/10.1007/s00253-009-2280-5

10. Gibson LJ (2012) The hierarchical structure and mechanics of plant materials. J R Soc Interface 9(76):2749-2766. https://doi. org/10.1098/rsif.2012.0341

11. Kumari D, Singh R (2018) Pretreatment of lignocellulosic wastes for biofuel production: A critical review. Renew Sustain Energy Res 90:877-891. https://doi.org/10.1016/j.rser.2018.03.111

12. Jönsson LJ, Martín C (2016) Pretreatment of lignocellulose: Formation of inhibitory by-products and strategies for minimizing their effects. Bioresour Technol 199:103-112. https://doi. org/10.1016/j.biortech.2015.10.009

13. Huang C-F, Jiang Y-F, Guo G-L, Hwang W-S (2011) Development of a yeast strain for xylitol production without hydrolysate detoxification as part of the integration of co-product generation within the lignocellulosic ethanol process. Bioresour Technol 102(3):3322-3329. https://doi.org/10.1016/j.biortech.2010.10.111

14. Ling H, Teo W, Chen B, Leong SSJ, Chang MW (2014) Microbial tolerance engineering toward biochemical production: from lignocellulose to products. Curr Opin Biotechnol 29:99-106. https ://doi.org/10.1016/j.copbio.2014.03.005 
15. Mussatto SI, Teixeira JA (2010) Lignocellulose as raw material in fermentation processes. In: Méndez-Vilas A (ed) Current research, technology and education topics in applied microbiology and microbial biotechnology. Formatex, Badajoz, pp 897-907

16. Ludwig D, Amann M, Hirth T, Rupp S, Zibek S (2013) Development and optimization of single and combined detoxification processes to improve the fermentability of lignocellulose hydrolyzates. Bioresour Technol 133:455-461. https://doi.org/10.1016/j. biortech.2013.01.053

17. Tu W-L, Hsu T-C, Wang C-A, Guo G-L, Chao Y (2019) Using novel Lactobacillus plantarum to produce lactic acid from lignocellulosic biomass in an integrated simultaneous saccharification and fermentation process. BioResources 14(2):13

18. van der Pol EC, Vaessen E, Weusthuis RA, Eggink G (2016) Identifying inhibitory effects of lignocellulosic by-products on growth of lactic acid producing micro-organisms using a rapid small-scale screening method. Bioresour Technol 209:297-304. https://doi. org/10.1016/j.biortech.2016.03.037

19. Narayanan N, Roychoudhury PK, Srivastava A (2004) L (+) lactic acid fermentation and its product polymerization. Electron $\mathrm{J}$ Biotechnol 7(2):167-U162

20. Garlotta D (2001) A literature review of poly(lactic acid). J Polym Environ 9(2):63-84. https://doi.org/10.1023/A:1020200822435

21. Patnaik R, Louie S, Gavrilovic V, Perry K, Stemmer WP, Ryan CM, del Cardayré S (2002) Genome shuffling of Lactobacillus for improved acid tolerance. Nat Biotechnol 20(7):707-712. https:// doi.org/10.1038/nbt0702-707

22. Abbott DA, Suir E, van Maris AJA, Pronk JT (2008) Physiological and transcriptional responses to high concentrations of lactic acid in anaerobic chemostat cultures of Saccharomyces cerevisiae. Appl Environ Microbiol 74(18):5759-5768. https://doi. org/10.1128/aem.01030-08

23. Pieterse B, Leer RJ, Schuren FHJ, van der Werf MJ (2005) Unravelling the multiple effects of lactic acid stress on Lactobacillus plantarum by transcription profiling. Microbiology $151(\mathrm{Pt}$ 12):3881-3894. https://doi.org/10.1099/mic.0.28304-0

24. Madzingaidzo L, Danner H, Braun R (2002) Process development and optimisation of lactic acid purification using electrodialysis. J Biotechnol 96(3):223-239. https://doi.org/10.1016/s0168 -1656(02)00049-4

25. Magni C, de Mendoza D, Konings WN, Lolkema JS (1999) Mechanism of citrate metabolism in Lactococcus lactis: resistance against lactate toxicity at low pH. J Bacteriol 181(5):1451-1457

26. Machii M, Watanabe S, Zendo T, Chibazakura T, Sonomoto K, Shimizu-Kadota M, Yoshikawa H (2013) Chemically defined media and auxotrophy of the prolific 1-lactic acid producer Lactococcus lactis IO-1. J Biosci Bioeng 115(5):481-484. https://doi. org/10.1016/j.jbiosc.2012.11.024

27. Zhang Y, Vadlani PV (2015) Lactic acid production from biomassderived sugars via co-fermentation of Lactobacillus brevis and Lactobacillus plantarum. J Biosci Bioeng 119(6):694-699. https ://doi.org/10.1016/j.jbiosc.2014.10.027

28. Kanagachandran K, Stanbury PF, Hall SJ, Ishizaki A (1997) Glucose repression of xylose utilisation by Lactococcus lactis IO-1. Biotechnol Lett 19(9):923-925. https://doi.org/10.1023/a:10183 10325607

29. Cui F, Li Y, Wan C (2011) Lactic acid production from corn stover using mixed cultures of Lactobacillus rhamnosus and Lactobacillus brevis. Bioresour Technol 102(2):1831-1836. https://doi. org/10.1016/j.biortech.2010.09.063

30. Cicco N, Lanorte MT, Paraggio M, Viggiano M, Lattanzio V (2009) A reproducible, rapid and inexpensive folin-ciocalteu micro-method in determining phenolics of plant methanol extracts. Microchem J 91(1):107-110. https://doi.org/10.1016/j. microc.2008.08.011
31. de Man JC, Rogosa M, Sharpe ME (1960) A medium for the cultivation of Lactobacilli. J Appl Microbiol 23:130-135

32. Okano K, Yoshida S, Yamada R, Tanaka T, Ogino C, Fukuda H, Kondo A (2009) Improved production of homo-d-lactic acid via xylose fermentation by introduction of xylose assimilation genes and redirection of the phosphoketolase pathway to the pentose phosphate pathway in 1-lactate dehydrogenase gene-deficient $\mathrm{Lac}$ tobacillus plantarum. Appl Environ Microbiol 75(24):7858-7861

33. Erlandson KA, Park JH, El Khal W, Kao HH, Basaran P, Brydges S, Batt CA (2000) Dissolution of xylose metabolism in Lactococcus lactis. Appl Environ Microbiol 66(9):3974-3980. https://doi. org/10.1128/aem.66.9.3974-3980.2000

34. Miyoshi A, Azevedo V, Jamet E, Renault P, Commissaire J, Langella P (2004) A xylose-inducible expression system for Lactococcus lactis. FEMS Microbiol Lett 239(2):205-212. https://doi. org/10.1016/j.femsle.2004.08.018

35. Kim J-H, Shoemaker SP, Mills DA (2009) Relaxed control of sugar utilization in Lactobacillus brevis. Microbiology 155(4):1351-1359

36. Guo W, Jia W, Li Y, Chen S (2010) Performances of Lactobacillus brevis for producing lactic acid from hydrolysate of lignocellulosics. Appl Biochem Biotechnol 161(1-8):124-136. https://doi. org/10.1007/s12010-009-8857-8

37. Cubas-Cano E, González-Fernández C, Ballesteros M, TomásPejó E (2018) Biotechnological advances in lactic acid production by lactic acid bacteria: lignocellulose as novel substrate. Biofuel Bioprod Biorefin 12(2):290-303. https://doi. org/10.1002/bbb. 1852

38. Jeong KH, Israr B, Shoemaker SP, Mills DA, Kim J (2016) Impact of lactic acid and hydrogen ion on the simultaneous fermentation of glucose and xylose by the carbon catabolite derepressed Lactobacillus brevis ATCC 14869. J Microbiol Biotechnol 26(7):1182-1189. https://doi.org/10.4014/jmb.1512.12038

39. Djordjevic GM, Tchieu JH, Saier MH (2001) Genes involved in control of galactose uptake in Lactobacillus brevis and reconstitution of the regulatory system in Bacillus subtilis. J Bacteriol 183(10):3224-3236. https://doi.org/10.1128/ jb.183.10.3224-3236.2001

40. Ye JJ, Saier MH (1995) Allosteric regulation of the glucose:H+ symporter of Lactobacillus brevis: cooperative binding of glucose and HPr(ser-P). J Bacteriol 177(7):1900-1902

41. Ye JJ, Saier MH (1995) Cooperative binding of lactose and the phosphorylated phosphocarrier protein $\mathrm{HPr}(\mathrm{Ser}-\mathrm{P})$ to the lactose/H+ symport permease of Lactobacillus brevis. Proc Natl Acad Sci USA 92(2):417-421. https://doi.org/10.1073/ pnas.92.2.417

42. Xiao H, Gu Y, Ning Y, Yang Y, Mitchell WJ, Jiang W, Yang S (2011) Confirmation and elimination of xylose metabolism bottlenecks in glucose phosphoenolpyruvate-dependent phosphotransferase system-deficient Clostridium acetobutylicum for simultaneous utilization of glucose, xylose, and arabinose. Appl Environ Microbiol 77(22):7886-7895. https://doi.org/10.1128/aem.00644 $-11$

43. Kaur G (2019) Non-refined carbon sources and microbial performance. In: Brar SK, Das RK, Sarma SJ (eds) Microbial sensing in fermentation. Wiley-Blackwell, New York, p 344

44. Hua Y, Wang J, Zhu Y, Zhang B, Kong X, Li W, Wang D, Hong J (2019) Release of glucose repression on xylose utilization in Kluyveromyces marxianus to enhance glucose-xylose co-utilization and xylitol production from corncob hydrolysate. Microb Cell Fact 18(1):24. https://doi.org/10.1186/s12934-019-1068-2

45. Lane S, Xu H, Oh EJ, Kim H, Lesmana A, Jeong D, Zhang G, Tsai C-S, Jin Y-S, Kim SR (2018) Glucose repression can be alleviated by reducing glucose phosphorylation rate in Saccharomyces cerevisiae. Sci Rep 8(1):2613. https://doi.org/10.1038/s41598-01820804-4 
46. Ramos CL, Thorsen L, Schwan RF, Jespersen L (2013) Strainspecific probiotics properties of Lactobacillus fermentum, Lactobacillus plantarum and Lactobacillus brevis isolates from Brazilian food products. Food Microbiol 36(1):22-29. https://doi. org/10.1016/j.fm.2013.03.010

47. Chaillou S, Bor YC, Batt CA, Postma PW, Pouwels PH (1998) Molecular cloning and functional expression in Lactobacillus plantarum 80 of xylT, encoding the D-xylose-H+ symporter of Lactobacillus brevis. Appl Environ Microbiol 64(12):4720-4728

48. Garde A, Jonsson G, Schmidt AS, Ahring BK (2002) Lactic acid production from wheat straw hemicellulose hydrolysate by Lactobacillus pentosus and Lactobacillus brevis. Bioresour Technol 81(3):217-223. https://doi.org/10.1016/S0960-8524(01)00135-3

49. Liu S, Dien BS, Nichols NN, Bischoff KM, Hughes SR, Cotta MA (2007) Coexpression of pyruvate decarboxylase and alcohol dehydrogenase genes in Lactobacillus brevis. FEMS Microbiol Lett 274(2):291-297. https://doi.org/10.1111/j.1574-6968.2007.00849 .x

50. Snelders J, Dornez E, Benjelloun-Mlayah B, Huijgen WJJ, de Wild PJ, Gosselink RJA, Gerritsma J, Courtin CM (2014) Biorefining of wheat straw using an acetic and formic acid based organosolv fractionation process. Bioresour Technol 156:275-282. https://doi.org/10.1016/j.biortech.2014.01.069

51. Mohagheghi A, Linger JG, Yang SH, Smith H, Dowe N, Zhang M, Pienkos PT (2015) Improving a recombinant Zymomonas mobilis strain $8 \mathrm{~b}$ through continuous adaptation on dilute acid pretreated corn stover hydrolysate. Biotechnol Biofuels 8:9. https ://doi.org/10.1186/s13068-015-0233-Z

52. Silva DDV, Arruda PV, Dussan KJ, Felipe MGA (2014) Adaptation of Scheffersomyces Stipitis cells as a strategy to the improvement of ethanol production from sugarcane bagasse hemicellulosic hydrolysate. Chem Eng Trans 38:427-432. https://doi. org/10.3303/cet1438072

53. Wordofa GG, Kristensen M (2018) Tolerance and metabolic response of Pseudomonas taiwanensis VLB120 towards biomass hydrolysate-derived inhibitors. Biotechnol Biofuels. https://doi. org/10.1186/s13068-018-1192-y
54. Wang SZ, He ZJ, Yuan QP (2017) Xylose enhances furfural tolerance in Candida tropicalis by improving NADH recycle. Chem Eng Sci 158:37-40. https://doi.org/10.1016/j.ces.2016.09.026

55. Boguta AM, Bringel F, Martinussen J, Jensen PR (2014) Screening of lactic acid bacteria for their potential as microbial cell factories for bioconversion of lignocellulosic feedstocks. Microb Cell Fact 13:16. https://doi.org/10.1186/s12934-014-0097-0

56. Ouyang J, Ma R, Zheng Z, Cai C, Zhang M, Jiang T (2013) Open fermentative production of 1-lactic acid by Bacillus sp. strain NL01 using lignocellulosic hydrolyzates as low-cost raw material. Bioresour Technol 135:475-480. https://doi.org/10.1016/j. biortech.2012.09.096

57. Nomura Y, Hallsworth JE, Iwahara M, Tanaka T, Ishizaki A (1998) Rapid and efficient production of L-lactate from xylose using electrodialysis culture-associated product separation. World J Microbiol Biotechnol 14(6):911-916. https://doi. org/10.1023/A:1008822422546

58. Huang H, Guo X, Li D, Liu M, Wu J, Ren H (2011) Identification of crucial yeast inhibitors in bio-ethanol and improvement of fermentation at high $\mathrm{pH}$ and high total solids. Bioresour Technol 102(16):7486-7493. https://doi.org/10.1016/j.biort ech.2011.05.008

59. Mills TY, Sandoval NR, Gill RT (2009) Cellulosic hydrolysate toxicity and tolerance mechanisms in Escherichia coli. Biotechnol Biofuels 2(1):26. https://doi.org/10.1186/1754-6834-2-26

60. Klinke HB, Thomsen AB, Ahring BK (2004) Inhibition of ethanol-producing yeast and bacteria by degradation products produced during pre-treatment of biomass. Appl Microbiol Biotechnol 66(1):10-26. https://doi.org/10.1007/s00253-004-1642-2

61. Mussatto SI, Roberto IC (2004) Alternatives for detoxification of diluted-acid lignocellulosic hydrolyzates for use in fermentative processes: a review. Bioresour Technol 93(1):1-10. https://doi. org/10.1016/j.biortech.2003.10.005

Publisher's Note Springer Nature remains neutral with regard to jurisdictional claims in published maps and institutional affiliations. 